\title{
Teaching Internship in Math Teacher Education
}

\author{
https://doi.org/10.3991/ijet.v14i12.10449 \\ Adilzada Sharzadin, Issatay Utebayev, Nazym Syzdykova, Bayan Shaushekova, \\ Umitzhan Kossybayeva ${ }^{(凶)}$ \\ apronina@yahoo.com \\ Aidos Mukhatayev \\ Center for Bologna process and academic mobility, Karaganda, Republic of Kazakhstan \\ Sayat Kurymbayev \\ Karaganda State University, Karaganda, Republic of Kazakhstan
}

\begin{abstract}
Given the current requirements for teaching internship, the issue of improving bachelor's preparation for math teachers may be considered relevant. Thus, the purpose of this research is to analyze the process of preparing bachelors majoring in math teaching within the system of higher education in the Republic of Kazakhstan. The existence of various programs and special courses on math teaching points to a high significance of specialist training for the current education system in Kazakhstan. Various advanced courses on math teaching were mainly aimed at improving the students' results in final assessment in mathematics, as well as at developing their skills through teaching internships. A comparison we were made between modern teaching internship and the relevant experience in the 20th century. The students of Karaganda E.A. Buketov State University were offered to answer the questionnaire - the science and math test. Their answers were used as a basis for our analysis and conclusions. The share of students who have successfully completed educational programs in science and mathematics was $80 \%$. The materials of this article can serve as a basis for further researches on the elaboration of industrial and teaching internship programs for various fields of bachelor's preparation.
\end{abstract}

Keywords - Teaching Internship Innovative Teacher, Methodology improvement, Master Class, New Technology, mathematics Education

\section{Introduction}

Mathematics, which we learn, encourages using it in everyday life. What is the teacher's role? What must the teacher do to maximize the students' learning experience? Learning through problem solving has long become a popular slogan, and a great deal was invented and understood in this regard [1]. Today, however, one also hears about new kinds of problems, about a new system of organizing themappropriately, these are subjects of ongoing discussion in both countries. Technological discoveries have the greatest impact on math education, inasmuch as they have 
changed our understanding of the goals and the content of math education. The National Mathematics Advisory Panel reported that mathematics is the invisible culture of our age. This is especially evident in our technology-rich society. The article considers the role of teaching internship in math teacher education [2]. To be effective, math teachers need to possess a sound knowledge of the subject, a good understanding of how to teach it and the flexibility to adapt their methods to the needs of all students. In addition to the concern over ageing math teachers and an unequal gender imbalance in some countries, a great challenge is to improve the competences of math teachers [3]. In most European countries, central guidelines for initial teacher education programmes cover a wide range of areas of mathematical knowledge and teaching skills. This is echoed by the findings of the Eurydice pilot survey of initial teacher education programmes (SITEP).

The standards for math teaching and related competencies are a subject of intensive discussions [4]. In Russia, an important development is the nationwide implementation of the Unified State Examination (USE) in mathematics (and other subjects). The USE has two functions: first, to control and unify the high school diploma examinations and, second, to serve as the main criterion for entering university (thus replacing the entrance exams organized by the universities themselves in previous years) [5]. This year the selection of math problems at the USE was generally regarded as very appropriate, nevertheless, there is a strong feeling in the mathematics education community that the USE should be replaced by two separate examinations, each performing one of the two functions mentioned above.

However, both SITEP results and official regulations and recommendations indicate that teaching mathematics to a diverse range of students and in a gendersensitive way are competencies that need to be strengthened in future programmes [6]. Primary teachers are the generalist teachers, but given the importance given to mathematics, there are moves to introduce more mathematically advanced specialists. In Austria, there are recent innovations in teacher education that imply the establishment of education infrastructure that would support teachers both at the preservice and in-service level [7]. For example, a number of regional networks for teacher collaboration, six national and eighteen regional subject-didactics centres have been established (IMST project). In Germany, a German Centre for Continuous Professional Development (DZLM) for mathematics teachers was established as an equivalent of the successful National Centre of Excellence of Teaching Mathematics (NCETM) in England [8]. The changes that are currently taking place within the education system of the Republic of Kazakhstan will ensure the continuity of the education program. In its turn, this will favour the development of a fully established highquality personality that is able to perform at a high level with the most benefit, and thus the development of national intellectual potential.

New education standards imply active individual work that allows mastering both field-specific knowledge and those kinds of activity that characterize their future profession. Students may be stimulated to individual work via different methods applied in organise lectures and practical lessons. The use of such methods makes lectures more review-like in their character, while practical classes acquire the features of a seminar [9-11]. 
The education system must serve as the main source of developing intellectual and value-related potential of society. It is evident that the teacher occupies the key position within this system. His professional background and personal qualities exert the most important influence upon training future specialists [11]. Nowadays, teacher is not simply a person who provides students with new information, but who is able to engage them into an active process of acquiring knowledge, learning the actions they will need in their work, to develop their creative activity [12-14].

This is especially important in teaching mathematics since it is fundamental science. Its methods are actively applied in numerous natural science disciplines, such as physics, chemistry and even biology $[15,16]$.

Teaching internship as part of specialist training is one of the main forms of their professional development that allows synthesizing theoretical knowledge and practical experience [17]. Thus, the purpose of the article is to consider the role of teaching internship in specialist preparation.

\section{Methods}

The analysis of pedagogical and national education projects allows obtaining objective data on organizing the teaching process in national educational institutions. The legal documents on teaching internship that are approved by the Ministry of Education and Science of the Republic of Kazakhstan were analyzed. Besides, a comparison was made between modern teaching internship and the relevant experience in the $20^{\text {th }}$ century. Students of the E.A. Buketov Karaganda State University were offered to answer the questionnaire. Their answers were used as a basis for our analysis and conclusions.

For this purpose, we analyzed a range of documents and educational resources, such as The State Program of Education Development in the Republic of Kazakhstan for 2011-2020 (2010) and the "Kazakhstan-2050" Strategy: Education Priorities (2012).

The analysis touched upon higher education standards that are currently established in Kazakhstan in order to identify the shortcomings in bachelor's preparation programs. Our research is aimed at identifying the objectives of teaching internship in mathematical education in the Republic of Kazakhstan. The State should contribute to the development of this resource. Without educated people, it would be impossible to develop a modern infrastructure, establish an effective state mechanism and create a favourable business environment. Political will and comprehensive state support will underlie these reforms. In order to trace this tendency, a research was conducted among the third and fourth-year students of E.A. Buketov Karaganda State University, at the Faculty of Mathematics and Information Technology.

The program will be realized in two stages: 2011 - 2015 and 2016 -2020 (see Table 1). The first stage of the program's implementation (2011-2015) provides for the elaboration of the models of education development in separate directions, their approbation, as well as the launch of large-scale events and experiments. The second stage (2016-2020) will focus on the implementation of the events aimed at the acqui- 
sition of equipment, investing in solution of the education development problems (modernization of education infrastructure and other high-value works, staffing, information and methodical support), introduction and dissemination of results gained at the previous stages. The indicators characterizing the course of the Program's implementation for every year and the impact of the program events on education system are to be changed at each stage.

Table 1. The content of the program of education development

\begin{tabular}{|l|l|}
\hline 2011-2015 & \begin{tabular}{l} 
1. Development of a new financial-economic mechanism. \\
2. Establishment of the e-learning system. \\
3. The Basis for National Qualification System established. \\
4. School and university education programs integrated. \\
5. Integration of higher education, science and production started. \\
\hline 1. Competitiveness and effectiveness of economy of the country will be increased, due to the \\
improvement of human capital quality and rational use of labour resources \\
2. The material-and-technical base of educational institutions will be strengthened due to the use \\
of new principles of design, construction and reconstruction. Old and dilapidated educational \\
facilities will be liquidated. Technological and social infrastructure of education (renewed \\
kitchens and gyms, car park, computers, etc.) will be modernized. \\
3. More efficient use of budgetary funds. \\
4. Access to education, its quality and transparency will be increased, corporate governance \\
principles will be implemented. \\
5. A new financial and economic mechanism will be implemented; financing of secondary, \\
technical and vocational education institutions will be based on per capita normative principles \\
while qualification upgrading system will be financed on a voucher basis. \\
6. Implementation of various forms of preschool upbringing and education, the formation of \\
children's readiness to school, ensuring early positive socialization. \\
7. Provision of all students with online access to worldwide educational information resources. \\
8. Implementation of a regional system of education quality assessment.
\end{tabular} \\
\hline
\end{tabular}

Negative trends in staffing the universities are observed: there are no systematic measures on faculty training; outside employment is widely practised. Material and technical resources of Kazakhstani universities are renewed at a slow pace. Universities do not follow the established norms of library collection updating either for humanities or for technical professions. In many disciplines, textbooks are not developed or have small circulations. Information resources of universities are not united, and library fund is scattered. There is a lack of educational services funding in state support mechanisms.

The priorities of economic development are the integration of education, science and industry, the development of postgraduate education, science and industry, and the development of postgraduate education based on modern science and technology. A number of issues in the science sector remain unresolved. Outdated material-andtechnical base and laboratory equipment do not allow conducting qualitative research. The insufficient amount of design institutes and construction agencies undermines the transfer of technologies into production. There is no mechanism of cooperation between design institutes, universities, construction bureaus and industry. One of the most important tasks of the education system modernization is to form an intellectual nation with competitive knowledge, creative thinking, as well as high civil and moral principles, patriotism and social responsibility. 
The process of educational reform in the country is based on strategic documents. The main driver is the executive power: the Government of the Republic of Kazakhstan and the authorized body in the field of education, the Ministry of Education and Science of RK. Legislative and executive bodies are involved in making decisions on the reforms in education. In the adoption of the Law in Education, the main role is played by the Parliament of the Republic of Kazakhstan. The approval of the State Programme of Education Development is carried out by the Decree of the President of the Republic of Kazakhstan. The Strategic Plan is approved by the Decree of the Government. The main driving force in this process is the Ministry for Education and Science, which initiates the development of all the above-mentioned strategic documents in the field of education and defines the main strategic goals and priorities for the development in education. Strategic goals and the orientation of the education reform are laid out in documents that are presented to the citizens during the annual President's speech. Other strategic documents include the Plan of the Nation "100 Concrete Steps: a Modern State for All" within five institutional reforms, the new economic policy "Nurly Zhol - the path to the future", a nationwide patriotic idea 'Mangilik El', etc. Major reforms in the field of higher and postgraduate education are associated with Kazakhstan joining the Bologna process. With the introduction of the Bachelor-Master-PhD system and the education credit system, the structure and content of the programmes are reviewed. In accordance with the European Qualifications Framework, National Qualifications Framework, Sectorial Qualifications Framework and professional standards were developed, the content of educational standards and training programmes were updated, and multilingualism in education was introduced in 65 universities. The modular principle of the formation of educational programmes allows the flexibility to build an individual course of study and to respond to labour market needs. It also contributes to the development of academic mobility and recognition of periods of study in a foreign university.

University management undergone modernization as well. Based on international experience, corporate governance principles were introduced. A gradual transition towards the autonomy of universities was implemented. In the national universities, Supervisory Boards and Boards of Trustees were created and endowment funds were formed. These reforms are designed to ensure the transparency of university management, their accountability to the society and to attract investments in higher education in accordance with foreign practices. Overall, the above reforms are expected to enhance the internationalisation of higher education in Kazakhstan and to strengthen its competitiveness and quality.

\section{Results}

The university as an integral part of education prepares highly qualified specialists and organizes teaching internships that are associated with curriculum-encompassed practice in school settings.

Teaching internship is aimed at enhancing the knowledge that was acquired within conventional settings with innovations made. 
A future specialist needs to develop within himself such a unique quality that would allow him to enhance one's own skills, learn effectively, and thus maintain competence. A future teacher must show the desire to teach, to work with children (as the main condition for a teaching profession), to be able to choose this profession and show love for children.

Indeed, if a person is not able to show love for children and a desire to work with them, he/she can't be a real teacher and improve his/her pedagogical skills.

A future teacher becomes truly initiative when he/she is engaged in student internships. In this relation, teaching internship is especially important, because a student can become a real teacher only with a balanced set of interrelated characteristics like educational background inclinations, skills, interests and theoretical knowledge. This is the main condition for improving the teaching skills and for further professional development.

Teaching internship in higher education institutions is regulated by the normative legal acts issued by the Ministry of Education and Science. It is based on the specific rules of conduct.

The Order № 107 of the Ministry of Education and Science of the Republic of Kazakhstan «On the Approval of the Rules of Organization and Conducting Teaching Internship and Determining the Organizations (Enterprises) as Basis for Internship" was issued on the 29 January 2016 and registered in the Ministry of Justice of the Republic of Kazakhstan on 4 March 2016 (registration number 3395).

This document sets the following main requirements:

1. General rules.

2. Teaching internship instructions.

3. A procedure of determining an organization for internship.

4. A list of education institutions (technical, professional, vocational). The description of teaching internship procedure.

5. Types of internship.

A summary of documents relating to all internship types at higher education faculties.

1. The main internship rules are based on typical programs.

2. Internship planning procedure (2017-2018 academic year).

3. Methodical guides on carrying out the tasks in all kinds of programs and student internship at a department (separate program). The program is approved by the dean of the faculty. Internship agreement, drawn up in two copies. A separate program for each academic year must be elaborated.

4. Diaries-reports that are written by students during their internship (must be kept for 2 years). Student reporting protocols filed by both the advisor and school teacher.

5. Summary record of the meeting and final conference.

6. A Final Report that summarizes the students' results (final internship exam, the degree of students' involvement, their progress, the measures that are taken in relation to the students that demonstrated unsatisfactory results, recommendations).

7. The plan elaborated by education institution and internship department. 


\section{Plan of actions.}

Teaching internship is one of the main forms of professional development within the system of specialist preparation that combines theoretical knowledge and practice.

As K.D. Ushinsky wrote, "You can read a book or a teacher's lecture, but the only way to learn how to teach is to learn through the long-term experience" [18].

\subsection{Interaction and mutual understanding of theory and practice.}

During his/her teaching internship, a student will be able to better know his/her professional specialization and to determine whether he/she is ready to engage in the future profession.

Active and long-term experience reveals the contradictions between accessibility and the need for education. This gap stimulates the desire to continue education.

The student improves one's own teaching by learning new material, so the teaching practice itself becomes better only in settings. At this point, internship is a great way to reflect on what was learnt, as well as to fiddle with ideas, to select appropriate methods, and to decide on associated activities.

The main goal of teaching internship is to strengthen and deepen the knowledge gained by the students in the learning process, to improve their skills and knowledge of the future profession.

The number of ways to prepare a future teacher is unlimited. Traditionally, school experience is the link between theoretical learning and the students' future career in school. Universities organize the student internship so that they could reflect on their professional skills and abilities, could get acquainted with the main types of educational work and opportunities for a subject-teacher to show his/her creativity [19].

During their teaching internship, future teachers should feel the need to work with students, study the psychology of communication, try to pick a key to each student, strengthen communication with students' parents, stimulate their skills of self-control, respect in relation to work and older people. These are the skills that will help school students to shape their behaviour. This initiative will be needed during the whole teaching internship.

The analysis in our research is based on the comparison between previous teaching internship experience (70-90s of the 20th century) and current practice.

In the $70-90$ s of the $20^{\text {th }}$ century, students gained the main social and teaching experience during their first two or three years of study. Practical part included the work with children of different ages and their parents. During the third year, the main locations for their practice included summer pioneer camps, extracurricular institutions and trade unions. Teaching internship started from the fourth or fifth year of study. The students tried themselves as subject teachers and teachers in general education institutions [20].

Pedagogical teams curated teaching internship. They were responsible for organizing social and teaching practice and ensured "the exchange of experience, mutual support and the most favourable conditions for the special work of practising students". 
Pedagogical teams favoured "the development of pedagogical skills of the students, oriented them in their future profession and taught the bases of social work" [21].

Many education institutions introduced students into teaching internship from their first years of study. During the second semester in the teacher university (80-90s of the $20^{\text {th }}$ century), the first-year students spent 4-6 hours a week in school and 9 weeks in education institutions. During this period, they familiarized with their working place, with schoolwork specifics, main documents and the requirements to a subject teacher [22].

The main criteria for assessing the results of teaching internship included the following:

- Theoretical and practical aspects of students' work (goals, objectives, content, methods and types of work);

- The formation level of their professional pedagogical skills;

- Their professional orientation and types of social activities (interest in relation to practice, love for children, responsibility for work, creative communication) [23, 24].

During the last decades, both higher education and general education institutions have changed their approach to organizing a teaching internship.

During the research, the following problems were identified (Figure 1):

1. The majority of students (86\%) understand that teaching internship is an important, necessary step for their professional development, whereas $32 \%$ of respondents do not demonstrate enough "psychological readiness" for it.

2. Students do not notice problems that relate to the organization of teaching internship: $14 \%$ of them think they have enough professional skills to work in school, whereas $55 \%$ believe that they do not need professional testing before "active" practice.

3. $45 \%$ of students express a desire to participate in master-classes conducted by experienced teachers, whereas $41 \%$ want to engage in teaching internship after those master-classes (for self-evaluation and to summarize one's knowledge).

Almost half of the students believe that in future they will work as teachers. 


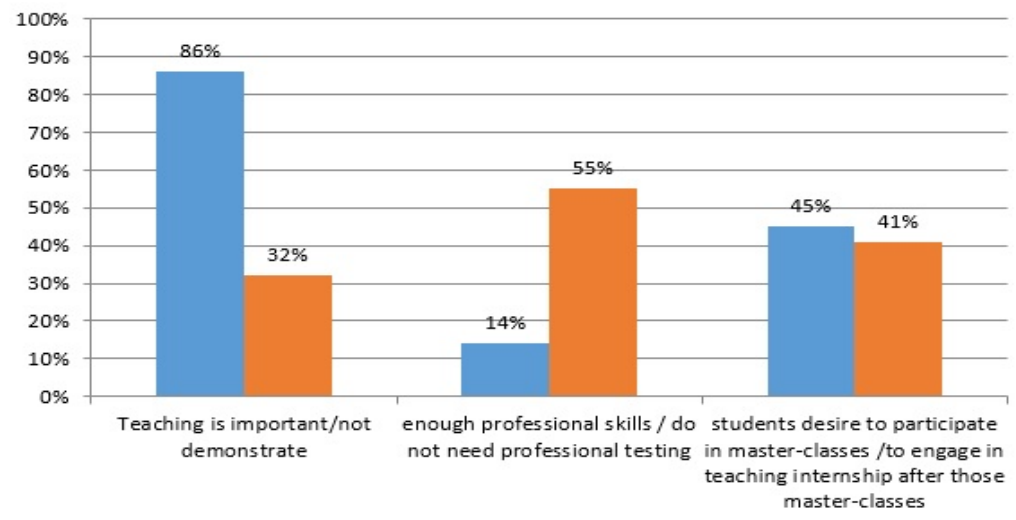

Fig. 1. Teaching internship results assessment

To enhance the role of teaching internship in modern pedagogical education, it is necessary to:

- Increase the number of hours for student internship and self-study

- Improve the structure, learning modes, teaching methods and content of the education program

- Draft the agreements that will allow establishing the contacts with main educational institutions

Thus, pedagogical experience plays an important role in advanced specialist preparation. It allows deepening and widening their theoretical knowledge, strengthening and developing their pedagogical skills, professional and personal qualities, stimulating pedagogical thinking, creative activity and independence. It is expected that teachers and students will make maximum use of the teaching internship potential in enhancing the students' self-study.

One of the main requirements for organizing teaching internship is to choose the place for an internship. Two schools in Karaganda served as a basis for our teaching internship: M. Zhumabayev school-gymnasium № 39 and secondary school № 66. These schools have qualified teachers in their staff who can effectively teach the latest achievements in pedagogical science.

\section{Discussion}

Despite a growing number of students with a different educational background, we still can observe a low level of attending different courses in education programs and advanced courses, a low development level of systematic and structured training of teachers and school leaders for schools in Kazakhstan [25]. If there are not enough foreign language teachers in the country, universities do not have teachers of other subjects in their staff, including mathematicians who can teach in a foreign language [26]. The same tendencies can be observed in Austria [27]. 
Only a few educational programs for managers in the field of education are aimed at solving the problems of creating multilingual education institutions [28].

Teaching internship takes place within a certain system. It includes psychologicalpedagogical practice in educational work, extracurricular practice, summer practice, trial lessons and classes, pre-graduation internship [17].

Thus, teaching internship plays an important role in specialist preparation. It allows widening and strengthening theoretical knowledge, forming their pedagogical skills and abilities, their professional and personal qualities, developing their pedagogical thinking, creative activity and independence.

It is also should be noted that, teaching internship cannot replace the following qualities that a math teacher must possess [15], such as:

1. Being aware of the personal and social significance of a teacher profession; understand the role of science in the development of society

2. Being able to reconsider one's own attitudes, to choose new forms and methods of work in light of actively developing science and changing social practice.

Austria successfully introduced the concept of "asymmetrical mobility" into the Bologna process and raised awareness among member countries, since only six countries have balanced patterns of student mobility [29]. This illustrates the complexity of the issue for Europe and shows that Austria is not the only country affected [8]. Together with its European partners, Austria has also managed to ensure that in addition to the " $20 \%$ by 2020 " mobility benchmark (i.e. whereby at least $20 \%$ of graduates by 2020 should have completed part of their studies abroad), "balanced mobility" has also been accepted as a European target for student mobility [30].

Foreign students and researchers are certainly welcome in Austria. The task, first of all, will be to get students to complete their degrees. Improvements will then be required in terms of access and integration for international graduates in the Austrian employment market, for the purposes of creating value for the national economy [31]. Measures should ensure, that the attraction to the Austrian employment market for international graduates who have studied in Austria will be enhanced. Autonomy of educational institutions is consistently expanding in terms of the content of education, $\mathrm{d}$ in terms of iversification of funding sources, in terms of introduction of Boards of Trustees and Supervisory Boards, reporting of rectors, etc. However, on many issues, the degree of centralization of decision-making is still high and universities do not have full autonomy regarding curriculum and admissions [32]. They must meet the standards related to the content of educational programmes, admission exams, completion of studies and the awarding procedures of academic degrees and quality assurance. It is not a surprise that experiencing with new teaching methods gives both positive and negative results, but the future development must seek to sort out the cases where the use of innovative e-learning methods outperform traditional methods. Such evidence is missing in the current research [33]. Research of these countries as Austria will be worthwhile order to provide credible evidence on the effectiveness of new technologies, it is necessary to conduct randomized controlled field experiments with the new technology [34]. Experimental evidence is indispensable for developing our understanding of teaching technologies. However, many argue that universities 
are just at the beginning of exploring the possibilities that e-learning innovations offer. For example, there are many universities in Germany, Austria and another started to offer Massive Open Online Courses (MOOCs) [35]. These virtual courses are usually free and open to anyone who wants to participate. The design of the courses often has a focus is interactivity. Since the number of students, who enroll in MOOCs, is too large for standard student-lecturer interaction, innovative online tools serve as interactive the element [35]. The network that is established among MOOC students plays a significant role in the course design. Brennan presents an interesting overview of how MOOCs can resolve some of the current challenges in higher education. Until then, effectiveness of MOOCs innovation in higher education is and ways of its implement in Kazakhstan are open issues.

\section{Conclusion}

There is a range of factors that negatively influence the quality of education and impede the development of industrial and educational fields. They include:

1. The lack of hours for an internship in schools

2. Low level of skills of the majority of graduates when they enter higher education institutions

3. Inconsistency between methodological, technological, organizational, personnel base of educational institutions, modern requirements for modernization and international standards

The major reforms of national education policies are reflected in the Law on Education and the State Programme for Education Development of the Republic of Kazakhstan for 2011-2020. A three-tier system of higher education and a credit system (an educational system for enhancement and assessment of the level of study and performance of higher education students, similar to the ECTS) were introduced and the structure and content of educational programmes were reviewed. These changes are associated with the joining of Kazakhstan to the Bologna Process; they are determined by the desire to achieve recognition of Kazakhstani diplomas abroad and to be integrated into the worldwide educational area. In accordance with the European Qualifications Framework, the National Qualifications Framework, Sectorial Qualifications Frameworks and professional standards have been developed. The share of university graduates who completed education under the public contract scheme and employed within their specialization in the first year after graduation - 78\%. Two Kazakhstani universities listed in the ratings of the world's best universities. The share of universities that passed independent national institutional accreditation according to international standards - $65 \%$. Progressive development and modernization of education in the Republic of Kazakhstan becomes possible due to the understanding of the importance of human capital development by the country's top officials and all-round support rendered while initiating and conducting reforms in education sector. The approaches to the development of educational programmes according to the description of learning outcomes and the Dublin descriptors have been changed. 
Teaching internship as the main part of preparing bachelors majoring in mathematics (math teachers) should provide a possibility for future teachers to directly interact with pupils and to be acquainted with relevant regulatory documents that are established in the Republic of Kazakhstan.

\section{References}

[1] P. Sahlberg, Finnish lessons: what can the world learn from educational change in Finland?, New York: Teachers College Press, 2011. https://doi.org/10.1080/00131946.2013.807262

[2] C. S. Ticknor, "Situated learning in an abstract algebra classroom", Educational Studies in Mathematics, Vol. 81, 3, 2012, pp. 307-323. https://doi.org/10.1007/s10649-012-9405-y

[3] N. Wasserman, T. Fukawa-Connelly, J.P. Mejia-Ramos and K. Weber, "Making real analysis relevant to secondary teachers: Building up from and stepping down to practice", Primus, Vol. 27, 6, 2016, pp 559-578. https://doi.org/10.1080/10511970.2016.1225874

[4] R. McCrory, R. Floden, J. Ferrini-Mundy, M.D. Reckase and S.L. Senk, "Knowledge of algebra for teaching: A framework of knowledge and practices", Journal for Research in Mathematics Education, Vol. 43, 5, 2012, 584-615.

https://doi.org/10.5951/jresematheduc.43.5.0584

[5] E.N. Walker, Beyond Banneker: Black mathematicians and the paths to excellence, Albany, NY: SUNY Press, 2016.

[6] J.E. Tarr, R.Q. Berry, E.N. Walker, C.L. Rasmussen, K.F. Hollebrands, C. Konold, K.B. Chval and K. King, "New assessments for new standards: The potential transformation of mathematics education and its research implications", Journal for Research in Mathematics Education, Vol. 44, 2, 2013, pp. 340-352. https://doi.org/10.5951/jresematheduc.44.2.0340

[7] A.Ya. Kanel-Belov, "Olympiads: a door to mathematics or sports?", Matematicheskoe prosveschenie, Vol. 3, 15, 2013, pp. 1-19.

[8] A.I. Sgibnev, Research problems for beginners, Moscow: MCCME, 2015.

[9] J. Danielewicz, Teaching selves: Identity, pedagogy, and teacher education, Suny Press, 2014.

[10] K. Zeichner, K.A. Payne and K. Brayko, "Democratizing teacher education", Journal of Teacher Education, Vol. 66, 2, 2015, pp. 122-135. https://doi.org/10.1177/0022487114560908

[11] L.E. Beyer and K. Zeichner, "Teacher education in cultural context: Beyond reproduction", In Critical studies in teacher education, Routledge, 2018, pp. 298-334. https://doi.org/10.4324/9780429450150-11

[12] T. S. Popkewitz, Critical studies in teacher education: Its folklore, theory and practice, Routledge, 2018.

[13] K. M. Zeichner, "The Struggle for the Soul of Teaching and Teacher Education in the US", In The Struggle for the Soul of Teacher Education, Routledge, 2017, pp. 31-51. https://doi.org/10.4324/9781315098074-2

[14] A.T. Pearson, The teacher: Theory and practice in teacher education, Routledge, 2016.

[15] S. Lerman, Encyclopedia of mathematics education, Springer, Dordrecht, 2018.

[16] S. Blömeke, F.J. Hsieh, G. Kaiser and W.H. Schmidt, "International perspectives on teacher knowledge, beliefs and opportunities to learn", Teachers education and development study in mathematics (TEDS-M), 2014. https://doi.org/10.1007/978-94-007-6437-8 2 
[17] D. Berk, R.M. Wieman and J. Hiebert, "Designing systems for continuously improving instruction: The case of teacher preparation mathematics courses", In Teachers, Teaching, and Reform, Routledge, 2017, pp. 124-147. https://doi.org/10.4324/9781315186559-7

[18] A.E. Berikhanova, Introduction to pedagogical specialties, Manual: Almaty, 2009, pp. 15. (in Kazakh)

[19] U.B. Zheksenbayeva, Competently oriented education in the modern school: educationalmethodical manual, Almaty, 2009, pp. 56.

[20] B.A. Abdykarimov, Zh.M. Mamerkhanova and M.G. Sokolova, Pedagogy of professional training, Karaganda, 2007, pp. 34.

[21] T.S. Mamantova, The history of mathematics in the preparation of the teacher, The academic methodical manual, 2014, pp. 78.

[22] T.G. Tcheshuina, Industrial practice as a factor in the formation of professional competence of students of a teacher training university, Tomsk, 2006, pp. 47.

[23] R.R. Shakhmarova, Methodical preparation of the future teacher of mathematics on the basis of the students' experience in the process of pedagogical practice, Omsk, 2003, pp. 54.

[24] G. Abilkassimova and G.K. Kaltayeva, "The contents and features of preparation of future teachers of vocational training (for example, discipline «The methods of professional education»)", Bulletin of the karaganda university, Vol. 1, 85, 2017, pp. 63

[25] L. Tungatarova, "Development of social informatics as a step of optimization the higher education process in the Republic of Kazakhstan", Development, Vol. 3, 1, 2015, pp. 98103.

[26] M. Yergebekov and Z. Temirbekova, "The Bologna process and problems in higher education system of Kazakhstan”, Procedia-Social and Behavioral Sciences, Vol. 47, 2012, pp. 1473-1478. https://doi.org/10.1016/j.sbspro.2012.06.845

[27] A. Parra, J.R. Mendes, P. Valero and M.V. Ubillús, "Mathematics Education in Multilingual Contexts for the Indigenous Population in Latin America", In Mathematics Education and Language Diversity, Springer International Publishing, 2016, pp. 67-84. https://doi.org/10.1007/978-3-319-14511-2_4

[28] M. Setati and J. Adler, "Between languages and discourses: Language practices in primary multilingual mathematics classrooms in South Africa", Educational studies in mathematics, Vol. 43, 3, 2000, pp. 243-269. https://doi.org/10.1023/a:1011996002062

[29] S. Bauernschuster, O. Falck and L. Woessmann, "Surfing alone? The Internet and social capital: Evidence from an unforeseeable technological mistake", Journal of Public Economics, Vol. 117, 2014, pp. 73-89. https://doi.org/10.1016/j.jpubeco.2014.05.007

[30] K.E. Cortes, J. Goodman and T. Nomi, "Intensive math instruction and educational attainment: Long-run impacts of double-dose algebra", Journal of Human Resources, forthcoming, Vol. 50, 1, 2014, pp. 108-158. https://doi.org/10.3386/w20211

[31] T. Falch, O.H. Nyhus and B. Strøm, "Causal effects of mathematics", Labour Economics, forthcoming Vol. 31, 2014a, pp. 174-187. https://doi.org/10.1016/j.labeco.2014.07.016

[32] J. Schwenkenberg and J. Vanderhoff, "Why do charter schools fail? An analysis of charter school survival in New Jersey", Contemporary Economic Policy, forthcoming, Vol. 33, 2, 2014. https://doi.org/10.1111/coep.12068

[33] Economist, "E-ducation: A long-overdue technological revolution is at last under way. / Education technology: Catching on at last: New technology is poised to disrupt Ame rica's schools, and then the world's", The Economist, Vol. 13, 2013, pp. 22-24.

[34] J. Westbrook, N. Durrani, R. Brown, D. Orr, J. Pryor, J. Boddy and F. Salvi, "Pedagogy, Curriculum, Teaching Practices and Teacher Education in Developing Countries", Report for the U.K. Department for International Development, 2015. 
[35] W. Bowen, M.M. Chingos, K. Lack and T. Nygren, "Interactive learning online at public universities: Evidence from a six-campus randomized trial", Journal of Policy Analysis and Management, Vol. 33, 2014, pp. 94-111. https://doi.org/10.1002/pam.21728

\section{Authors}

Adilzada Sharzadin Candidate of pedagogics, docent of the Department of transport and vocational training, Karaganda state University named after E. Buketov, Karaganda, Republic of Kazakhstan.

Issatay Utebayev Candidate of pedagogics, Head of the Department of transport and vocational training, Karaganda State University named after E. Buketov, Karaganda, Republic of Kazakhstan.

Nazym Syzdykova Candidate of Physical and Mathematical Sciences, assistant professor of Methods of teaching mathematics and computer science Department in Karaganda state University named after E. Buketov, Karaganda, Republic of Kazakhstan.

Bayan Shaushekova Candidate of pedagogics docent of the Department of Pedagody and methods of primary education, Karaganda State University named after E. Buketov, Karaganda, Republic of Kazakhstan.

Umitzhan Kossybayeva Candidate of pedagogics of the Department of Mathematics and information sciences thaching methodics chair, Karaganda State University named after E. Buketov, Karaganda, Republic of Kazakhstan.

Aidos Mukhatayev Candidate of pedagogics Deputy Director of Center for Bologna process and academic mobility, Karaganda, Republic of Kazakhstan.

Sayat Kurymbayev Candidate of pedagogics, Assistant professor of the Department of Transport and vocational training, Karaganda State University named after E. Buketov, Karaganda, Republic of Kazakhstan.

Article submitted 2019-03-11. Resubmitted 2019-04-29. Final acceptance 2019-04-29. Final version published as submitted by the authors. 